afternoon was spent seeing some of these at the Clinical Laboratory, Royal Infirmary. Amongst these demonstrations were Dr. R. K. S. Lim, demonstration of the mucoid cells of the stomach; Dr. E. P. Poulton and Dr. W. W. Payne, peristalsis of the human œsophagus; Mr. McClure, psychogalvanic reflex; and Prof. J. Meakins, respiration with de. creased volume per respiration, with and without oxygen, and effect of resistance to breathing on respiration at rest and whilst working.

\title{
The Week in West Africa
}

A $\mathrm{T}$ a meeting of the Royal Anthropological Insti$A$ tute held on December I3 Mr. Northcote W. Thomas read a paper on "The Week in West Africa." He said there were in West Africa a number of sub-divisions of the lunar month, such as 16-day periods, Io-day periods, and the like, the origin of which was either in the market or in some religious belief. There were, in addition, a number of shorter units, comparable to our week, of more uncertain crigin; they ranged in length from two to eight days. They were very rarely sub-divisions of the month, and there was reason, where the week is synchronised with the month, to suspect foreign influence. Generally speaking, the month in West Africa was of small importance and played no part in economic or religious life; it was reckoned from the day on which the new moon was first seen, but the native can only very rarely say of how many days it consists. There was no less uncertainty as to the length of the year; few, if any, tribes had any exact knowledge of its length. The calendar was sometimes adjusted by the recognition of two years of different length, as in Benin, where the female year seems to have been about 340 days in length.

The week has been traced to a religious origin. Webster has regarded the "rest day" as its germ, but the rest day is an institution of agricultural people, and there are many such peoples in Africa who have no week. On the other hand, the distribution of the market is practically conterminous with that of the week, and it is probable that the calendar first came into existence as a means of indicating the market day. We have, however, little or no evidence to show why the different units were chosen. A certain number of day-names are derived from names of deities, notably on the Gold Coast; but, generally speaking, the kind of work done on a given day or the market attended is the decisive factor, and consequently they are used only in a small area. To this there is one striking exception; the Ibo day-names, used also in a different order in Benin City, are found everywhere from the Niger to the Cross River, but we are ignorant of their meaning.

The four-day week of the Lower Niger, which appears to be independent of the week of the Congo, seems to occupy the largest area; but we know too little of the distribution of the five- and six-day weeks, especially in French territory, to make any very definite assertion. There is good reason to suppose that a non-Mohammedan seven-day week was known; some of these weeks are clearly expanded from an earlier four-day week, but they have native, not Arabic, names.

\section{Scientific Research and Industrial Development.}

$\mathrm{IN}$ a lecture on "The Benefits of Research to Corporations". (No. I8, R. and C. Series of Nat. Res. Council, U.S.A., 1921) Dr. Charles L. Reese, chemical director of the de Pont de Nemours Explosives Co., U.S.A., gives examples of the advantages which accrue when a large industrial concern is equipped with a staff capable of applying scientific knowledge to the improvement of materials and processes.

Before the war this important company had already systematised its procedure by developing a systern of records and costing, and had completed a number of investigations which had been the means of saving money, resulting, for example, in methods for shortening the time of separation of nitroglycerine from its acids, increasing its yield, preventing its freezing in dynamites, and for nitrating cellulose by the use of the mechanical dipper. Studies from the company's laboratories on the nitration of toluene and of the characteristics of nitrocellulose propellants became of great importance when war broke out, as did also a process for the recovery of a considerable proportion of the alcohol used in gelatinising the propellant, this leading to a direct saving in corn-estimated at ten million bushels-which thus escaped being fermented.

During the war enormous extensions were made by the company for the production of nitrocellulose powder, trinitrotoluene, picric acid, amatol, and tetryl, and in this connection it is stated that the staff of the chemical and mechanical research departments of the firm was increased in number from 212 to 987 , with an expenditure on experiment and research of NO. 2726 , VOL. IO9]
$3,360,000$ dollars for four years of the war, the output of military explosives being seven million tons.

Since the war the company has transferred its research organisation with success to the production of dyes, and is spending, and is prepared to spend, many millions of dollars on research to meet German competition, but protection is considered to be essential at present to the existence of the industry.

The address is interesting as giving an idea of the scope and the methods of a large chemical concern in utilising the services of scientific men for the investigation of new processes and the conservation of materials. A custom obtains with the company of recompensing inventors by means of a bonus in the form of the company's stock, in some cases sufficient to make them independent.

Little mention is made, however, of research on the theory of explosives, on which doubtless much work has been done by the staff. A few remarks may be made as to some subject-matter of the claims. Thus, while the mechanical dipper was undoubtedly an advance for obtaining output on the old pot. process of making nitrocellulose, the. Thomson displacement process as used in this country and in France also greatly reduces handling of the material and eliminates fuming off, which appears still to occur occasionally with the mechanical dipper. Much is made of the "work found necessary to develop satisfactory methods for loading that very successful high explosive developed in England known as amatol, a mixture of trinitrotoluene and ammonium nitrate," but it is understood that an enormous 